International Journal of Environmental Science Development \& Monitoring.

ISSN 2231-1289 Volume 8, Number 1 (2017), pp. 17-37

(C) Research India Publications

https://dx.doi.org/10.37622/IJESDM/8.1.2017.17-37

\title{
Assessment of Phytoremediation Potential of Solanum melongena $\mathrm{L}$.
}

\author{
Himshweta Singh' ${ }^{1}$, Shafeeq Ahmed Malik ${ }^{2}$, Anukrati ${ }^{3}$, Dr.Rohan D' Souza ${ }^{4}$, \\ Dr. Purti Chaturvedi ${ }^{5}$ \\ ${ }^{1,2,3}$ Students (Research Scholars), ${ }^{4,5}$ Assistant Professors, Dept. of Botany SLS, \\ Khandari Campus, DR. B.R. Ambedkar University, Agra.
}

\begin{abstract}
Urban soils are increasingly acting as a sink for a wide range of contaminants including heavy metals due to rapid pace of development. The most dangerous heavy metals are $\mathrm{Pb}, \mathrm{Hg}, \mathrm{Cd}, \mathrm{Sn}, \mathrm{Cr}, \mathrm{Zn}$ and $\mathrm{Cu}$. Phytoremediation may an effective and affordable technological solution used to extract or remove inactive metals and metal pollutants from contaminated soil. A Greenhouse study (60 days) was undertaken to assess the phytoremedial potential of Solanum melongena L. (brinjal) with respect to two heavy metals-Cu (at 50 and $100 \mathrm{mg} \mathrm{kg}^{-1}$ ) and $\mathrm{Cd}$ (at 25 and $50 \mathrm{mg} \mathrm{kg}^{-1}$ ). Data reveals that accumulation was metal specific. $\mathrm{Cu}$ was preferentially partitioned in shoots while the reverse was true for $\mathrm{Cd}$. Addition of $\mathrm{Cu}$ and $\mathrm{Cd}$ to the growth matrix was seen to inhibit chlorophyll content, root/shoot length and biomass in all treated plants. Roots were affected more than shoots and the inhibition increased with increasing metal concentration. However, the inhibition seemed to decrease as the study progressed. All metal treatments increased plant proline content in comparison to control. Cd was found more toxic compared to $\mathrm{Cu}$. The test plant could not be categorized exclusively as a phytoextractor/phytostabilizer for either $\mathrm{Cu}$ or $\mathrm{Cd}$. However, it was seen to translocate $\mathrm{Cu}$ to shoots quite efficiently.
\end{abstract}

Keywords: Phytoremediation, Phytoextractor, Contaminants, Chlorophyll cotent, Proline content, Bioaccumulation potential, Biomass, Root and Shoot length etc. 


\section{INTRODUCTION}

Heavy metal polluted plant-soils and waters of our ecological system described as surface environments that have been drastically affected by both anthropogenic and natural sources as well (USEPA 2005). Nowadays metal pollution is particularly of global concern which poses adverse effects on all the living beings directly or indirectly.

Copper $(\mathrm{Cu})$ and Cadmium $(\mathrm{Cd})$ at excessive concentrations are potentially toxic metals (PTM) to the environment. Both these metals are persistent pollutants because they are non biodegradable without intervention stay in soil for long period of time (Chantachon et al., 2004). $\mathrm{Cu}$ is an essential micronutrient which contributes to several physiological processes in plants. It is released into the environment through industrial operations such as metal forging, smelting, mining, sewage sludge applications etc. as well as from agricultural activities. $\mathrm{Cd}$ is hazardous heavy metal which is highly toxic to plants, animals and humans. It is released by heating system, power stations, urban traffic and from vehicular exhausts and fertilizers (Toppi and Gabrielli, 1999). Enormous amounts of metals in polluted soils might report decline in soil fertility and soil microbial activity, yield loss and disruption of food chain and ecological balance (Varun et al., 2011).

In recent years, scientists and engineers have started, to generate cost effective 'green' technologies that emphasizes use of microorganisms /biomass or live plants to clean contaminated sites. The approach represents an efficient alternative to traditional remediation systems. Phytoremediation, an innovative treatment has attracted a great deal of interest. It is the use of living organism- plants to extract metals from the soils (Phytoextraction) and restore polluted environmental sites to less harmful levels (Liang et al., 2009).

Another important guideline of phytoremediation is (phytostabilisation) which means adsorption and binding of contaminants in situ.

Several researchers have screened many plants as "hyperaccumulators" special accumulatring plants which can uptake toxic metal ions at levels in 1000s of ppm and "metal indicators" plants which reflect the levels of metal in soil. These plants are useful in absorption of pollutants.

Hyperaccumulators are extensively used for phytoremediation purposes. According to Ali (1999) the maximum range for copper hyperaccumulation should be more than $1000 \mu \mathrm{g} / \mathrm{g}$ and that for $\mathrm{Cd}$ more than $100 \mu \mathrm{g} / \mathrm{g}$. To exhibit efficient phytoextraction plants should have BAC (Bioabsorption coefficient) as well as TF (translocation factor) $>1$ (Fitz and Wenzel 2002). Few examples of promising phytoextractors are Phyla nodiflora, Datura stramonium and Chenopodium murale all three having TF values greater than 1 . 
It has been demonstrated that, fast growing, high-biomass accumulating plants, including agronomic crops possess the ability to tolerate and accumulate metals (Prasad and Fretias 2003) and may be better phytoremediators for waste lands like Zea mays L; Hordeum vulgare, Avena sativa and Brassica juncea etc.

In the Indian context, it appears logical that studies are taken up to generate feasibility data about such remediation methods thus in the present study carried out Solanum melongena L. (Brinjal), a warm weather hardy crop seems quite as a phytoremediator of soil polluted separately with $\mathrm{Cu}$ and $\mathrm{Cd}$ metals.

Eggplant, an important solanaceous crop that yields well under stress conditions, including drought. It is a perennial grown commercially as an annual crop. However, based on the metal tolerance, accumulating potential and good biomass produced the candidate plant might represent as a useful tool since it still holds promise for phytoremedial purpose and future studies.

\section{MATERIALS AND METHODS}

Selection of the test plant:-

\section{S. Melongena for phytoremedial purposes}

Aubergine seeds were used for the pot experiment. It belongs to family Solanaceae and attains height of 0.5-1.5 m. Leaves simple, alternate, ovate to oblong- ovate (7.5$15 \mathrm{~cm}$ long). Flowers are solitary or in few-flowered lateral cymes having toothed calyx which is persistent. The fruit is a large, smooth, glossy firm fleshed, pendent berry $(15 \mathrm{~cm}$ long). Seeds are embedded in flesh of fruit.

Physico-chemical properties of soil used:-

The content soil was unamended and its initial total $\mathrm{Cu}$, and $\mathrm{Cd}$ doses were $0.10 \pm$ $0.03 \mathrm{mg} \mathrm{Cu} \mathrm{kg}^{-1}$, and $0.04 \pm 0.01 \mathrm{mg} \mathrm{Cd} \mathrm{kg}^{-1}$, respectively. The $\mathrm{pH}$ of the soil used was 6-7.

Experimental Design:-

Uniform seeds were planted in triplicate in pots prepared with soil $(5 \mathrm{~kg})$ from the botanical garden of the college. Soil was amended with copper $(\mathrm{Cu})$ and cadmium (Cd) separately to each pot in increasing concentrations $50,100 \mathrm{mg} \mathrm{kg}^{-1}$ of $\mathrm{Cu}$ and 25 , $50 \mathrm{mg} \mathrm{kg}^{-1}$ of $\mathrm{Cd}$ respectively. Control set was comprised of uncontaminated soil. Aqueous solution of copper sulphate and cadmium nitrate were added due to higher solubility and easier availability to the plant. Pots, kept in random block design were watered as and when required in such a way to prevent loss of contaminants by leaching. Study was conducted in green house for about 60 days. At a regular interval of 30 days after treatment i.e. 30 and 60, 3 replicates of each treatment were taken apart for metal analysis. Unamended plants were maintained as controls to compare 
both physiological (Chlorophyll and proline content at every 15, 30 and 60 DAT) and growth (shoot and root lengths and dry biomass at every 30 and 60 DAT) with dismantaling of pots at every 30 and 60 DAT for heavy meatl analysis.

Collection of samples:-

At each test date (30 and 60 DAT) soil and plant samples were collected from 3 replicate sets for metal analysis. The soil samples were homogenized, air dried in dark, passed through $20 \mathrm{~mm}$ mesh sieve and stored in clean zip lock polythene bags in a refrigerator until further analysis. Apart from this plant samples were first washed with distilled water to remove adhering mud. They were further washed thoroughly 34 times with deionized water and were allowed to dry at room temperature in a dust free chamber.

Metal analysis:-

Soil, root and shoot samples from all three replicate sets were digested to obtain a clear soil profile using wet digestion method with $10 \mathrm{ml}$ of aqua regia, a mixture of concentrated $\mathrm{HCl} / \mathrm{HNO}_{3}(3: 1 \mathrm{v} / \mathrm{v})$ for $0.5 \mathrm{~g}$ of soil and plant samples and boiled on a hot plate until clear solution was observed. The filtrate in each case was analyzed for $\mathrm{Cd}$ and $\mathrm{Cu}$ content by Atomic Absorption Spectrophotometer (ANALYST 100, Perkin Elmer, USA).

Chlorophyll content in $S$. melongena leaf samples were determined on the bases of fresh weight. $40 \mathrm{mg}$ fresh leaves were soaked in $10 \mathrm{ml}$ of $80 \%$ acetone in a sealed bottle in a refrigerator to avoid the entry of light. After 5 days, optical density was calculated with the help of spectrophotometer at 645 and $663 \mathrm{~mm}$ respectively and content in the samples was calculated using accordant formulae

Chl 'a' $=\quad \underline{12.7(O . D . \text { at } 663 \mathrm{~nm})-2.69 \text { (O.D. at 645nm xvolume }}$

$1000 \mathrm{x}$ weight of material.

Chl 'b' $\quad=22.9$ (O.D. at $645 \mathrm{~nm})-4.68$ (O.D. at $663 \mathrm{~nm}) \times$ xvolume

$1000 \mathrm{x}$ weight of material.

Total Chl $=\quad 20.2($ O.D. at $645 \mathrm{~nm})-8.02($ O.D. at $663 \mathrm{~nm}) \times$ volume

$1000 \mathrm{x}$ weight of material.

Proline content was also estimated on fresh weight bases. $500 \mathrm{mg}$ of fresh leaves were crushed with $10 \mathrm{ml}$ of $3 \%$ sulphosalicylic acid and centrifuged for 20 mins. $2 \mathrm{ml}$ of supernantant was taken to which $2 \mathrm{ml}$ each of ninhydrin and glacial acetic acid were added. Solution was boiled and coolec for 30 mins. After which $4 \mathrm{ml}$ toluene was added. Toulene layer was colledted and the optical density was determined as $520 \mathrm{~nm}$. The content in samples was calculated using accordant 
formula.

$$
\begin{gathered}
\text { Proline }=\frac{\mu \mathrm{g} \text { proline }}{\mathrm{ml}} \times \frac{\text { toluene used }}{115.5} \times \frac{\text { sample wt. }}{0.5}=\frac{\mathrm{x}}{2} \times \frac{4}{115.5} \times \frac{5}{0.5} \\
=\frac{\mathrm{x}}{2} \times 0.346 \mu \mathrm{g} \mathrm{g}^{-1} \mathrm{fw}
\end{gathered}
$$

Besides this root and shoot length were measured with scale and root and shoot dry by biomass was obtained by drying the samples in oven for $48 \mathrm{hrs}$.

Assessment of bioaccumulation potential of plant:-

To evaluate the phytoaccumulation potential of plant species studied the following factors were calculated using the formulae as follows:

1.

$$
\text { Translocation Factor } \frac{[\mathrm{TF}]}{\mathrm{l}}=\frac{\text { Metal conc. in shoot }}{\text { Metal conc. in root }}
$$

$$
\text { Root Concentration Factor } \frac{[\mathrm{RCF}]=\quad \text { Metal conc. in root }}{\text { Metal conc. in soil }}
$$

3.

$$
\text { Bioabsorption Coefficient } \frac{[\mathrm{BAC}]=}{\mathrm{Metal} \text { conc. }} \text {. in shoot } \text { in soil }
$$

\section{RESULTS AND DISCUSSION}

Characterstics of Metal Uptake:-

The accumulation of $\mathrm{Cu}$ and $\mathrm{Cd}$ screened in plant and soil samples are presented in table1 The $\mathrm{Cu}$ content values in S. melongena root samples ranges between 10.8 $25.3 \mathrm{mg} \mathrm{kg}^{-1}$ from 30 - 60 days whereas in shoots they are in higher range of $21.4-$ $59.2 \mathrm{mg} \mathrm{kg}^{-1}$ respectively. The uptake of $\mathrm{Cu}$ in plant samples increased in proportion to its increased concentrations in soil samples. Maximum increased levels of $\mathrm{Cu}$ recorded were $25.3 \mathrm{mg} \mathrm{kg}^{-1}$ and $59.2 \mathrm{mg} \mathrm{kg}^{-1}$ in $S$. melongena root and shoot samples respectively both at $50-100 \mathrm{mg} \mathrm{kg}^{-1}$ concentrations.

Metal content in S. melongena at successive days of study.

\begin{tabular}{|c|c|c|c|c|c|}
\hline \multirow{2}{*}{ Metals } & \multirow{2}{*}{$\begin{array}{c}\text { Concentration } \\
\left(\mathbf{m g ~ k g}^{-1}\right)\end{array}$} & \multicolumn{2}{|c|}{30 DAT } & \multicolumn{2}{c|}{ 60 DAT } \\
\cline { 2 - 6 } & Shoot & Root & Shoot & Root \\
\hline \multirow{2}{*}{$\mathbf{C u}$} & $\mathbf{5 0}$ & $21.4 \pm 2.3$ & $10.8 \pm 0.6$ & $29.5 \pm 3.3$ & $18.3 \pm 3$ \\
\cline { 2 - 6 } & $\mathbf{1 0 0}$ & $44.6 \pm 5.4$ & $20.2 \pm 3.2$ & $59.2 \pm 13.3$ & $25.3 \pm 1.6$ \\
\hline \multirow{2}{*}{ Cd } & $\mathbf{2 5}$ & $6.4 \pm 0.5$ & $8.2 \pm 1.5$ & $9.6 \pm 2.5$ & $11.3 \pm 2.1$ \\
\cline { 2 - 6 } & $\mathbf{5 0}$ & $5.1 \pm 1.9$ & $10.5 \pm 0.7$ & $8.1 \pm 1.4$ & $18.7 \pm 2.4$ \\
\hline
\end{tabular}


An increase in $\mathrm{Cu}$ uptake and accumulation was recorded for both concentrations upto final day (60). Accumulation of $\mathrm{Cu}$ content was more in shoots as compared to roots. In genral, $\mathrm{Cu}$ tends to accumulate to root tissue with little translocated to the shoots (Marschner, 1995). This however does not seem to be obligatory. Similar studies have shown that $\mathrm{Cu}$ was preferentially accumulated in shoot in Chenopodium murale and Poa annua and in the roots in Calotropis procera (Varun et al., 2015). The toxic range varies from $20-100 \mathrm{mg} \mathrm{kg}^{-1}$ in plants (Fageria et al., 2002). $S$. melongena in this study accumulated $\mathrm{Cu}$ at $20-59 \mathrm{mg} \mathrm{Cu} \mathrm{kg}^{-1} \mathrm{dw}$ without marked toxicity symptoms indicating the potential of this plant to with stand $\mathrm{Cu}$ in soil upto highest concentration levels.

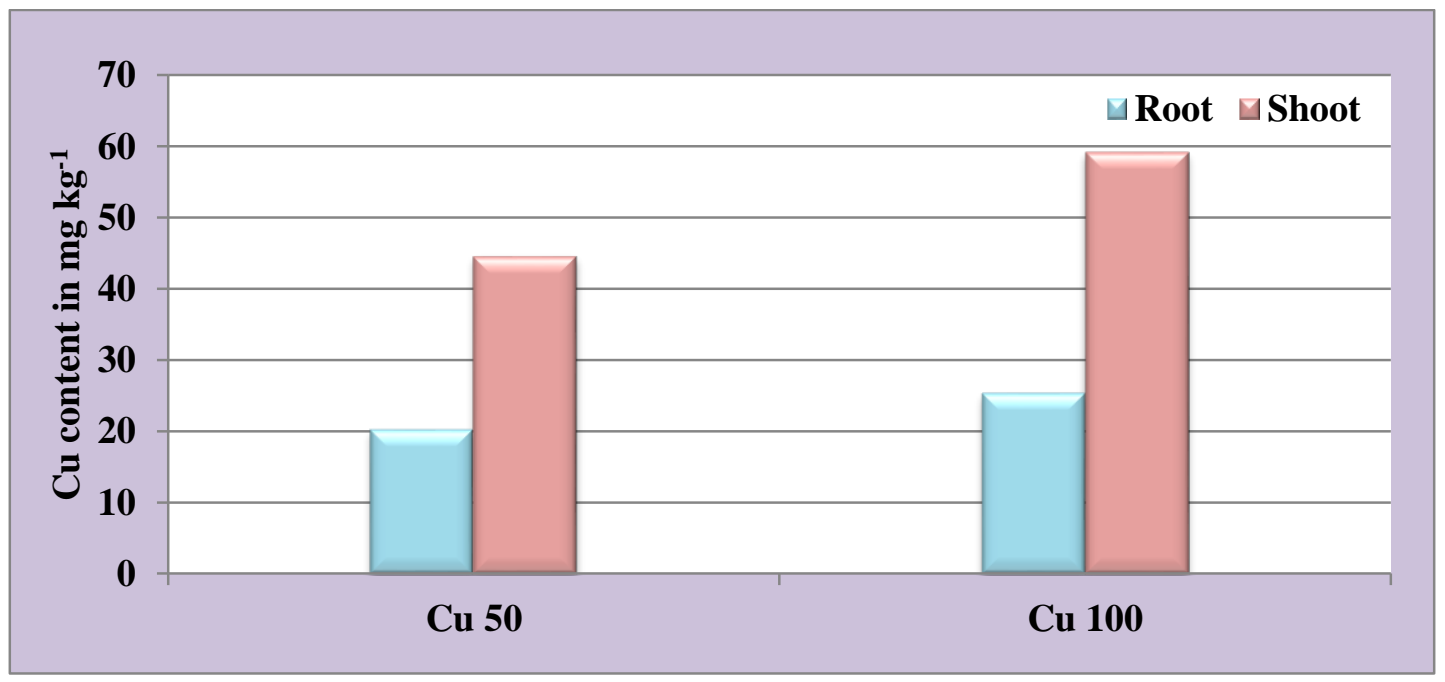

\section{Copper uptake in S. melongena at final day of study.}

Cd concentrations in root and shoot samples ranges between $8.2-18.7 \mathrm{mg} \mathrm{kg}^{-1}$ and 6.4-8.1 mg kg-1 respectively from 30-60 days both at 25 and $50 \mathrm{mg} \mathrm{kg}^{-1}$. A slight increase in $\mathrm{Cd}$ uptake and accumulation was recorded in respective plant upto final day. Accumulation of $\mathrm{Cd}$ content was more in roots as compared to shoots, the difference between root and shoot accumulation was more marked at higher concentration levels $\left(50 \mathrm{mg} \mathrm{kg}^{-1}\right)$. Uptake of Cd content was seen to increase with increasing soil concentrations but translocation to shoot decreased simultaneously. Many studies have demonstrated that Cd uptake by plants accumulates at higher doses in the root than in the stem and leaves.Including hyperaccumulators(Kupper et al., 2000). S. melongena showed similar trends in Cd partitioning.

In general uptake and accumulation trend in our study was $\mathrm{Cu}>\mathrm{Cd}$ which seems metal specific. $\mathrm{Cu}$ content was preferentially portioned in shoots while the reverse was true for $\mathrm{Cd}$. According to Intawongse and Dean (2006) the uptake of $\mathrm{Cd}, \mathrm{Cu}, \mathrm{Mn}$ 
and $\mathrm{Zn}$ by plants corresponded to the increasing level of soil contamination which was in order $\mathrm{Mn}>\mathrm{Zn}>\mathrm{Cd}>\mathrm{Cu}>\mathrm{Pb}$. Such increased uptake of $\mathrm{Cu}$ and $\mathrm{Cd}$ was noticed in this study too except $\mathrm{Cd}$ in roots of S. melongena. Herrero et al., (2003) reported that in Brassica napus, grown in contaminated soil, roots had maximum $\mathrm{Cd}$ content at lower levels, but at higher levels, roots and leaves become highest.

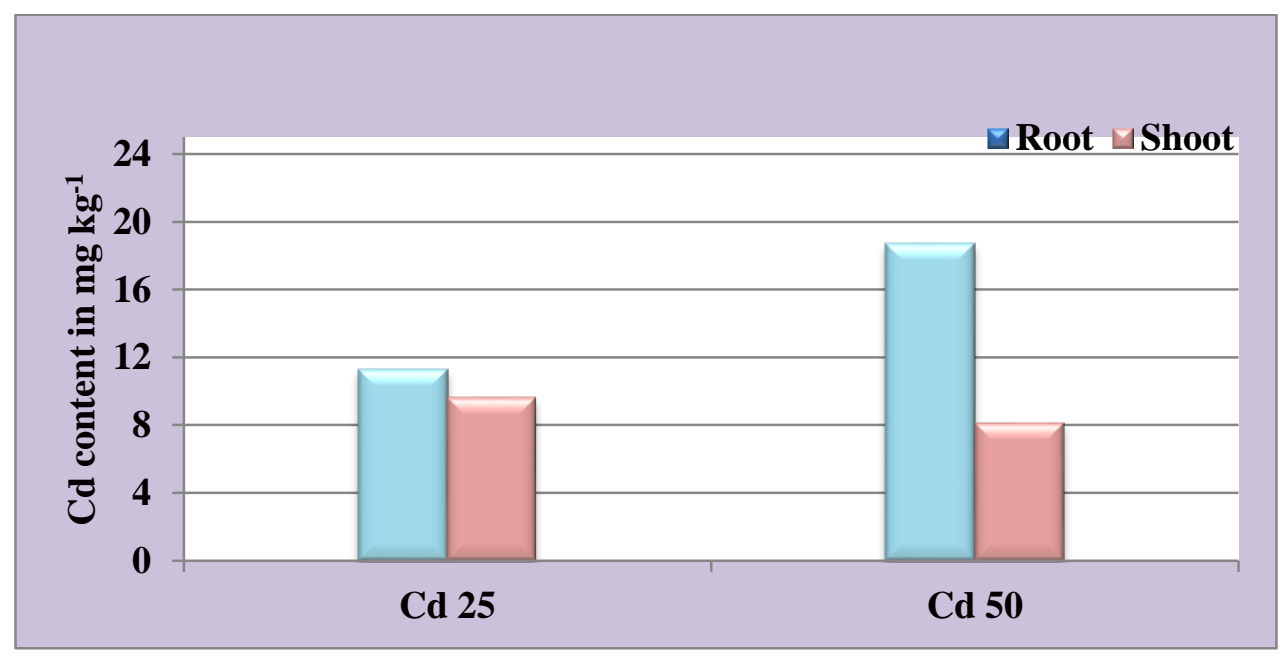

Cadmium uptake in S. melongena at final day of study.

\section{Reduction in metal content of soil:-}

Soil samples tested for $\mathrm{Cu}$ and $\mathrm{Cd}$ content in S. melongena showed percent reduction. This translates to $2.9 \%$ and $3.7 \%$ for $\mathrm{Cu}$ increasing levels from $50-100 \mathrm{mg} \mathrm{kg}^{-1}$ upto final day. Similarly $2.8 \%$ and $1.7 \%$ reduction translates to $\mathrm{Cd}$ increasing concentrations both at 25 and $50 \mathrm{mg} \mathrm{kg}^{-1}$ respectively. The reduction $\%$ of $\mathrm{Cu}$ and $\mathrm{Cd}$ soil samples was in the order $\mathrm{Cu} 100>\mathrm{Cu} 50>\mathrm{Cd} 25>\mathrm{Cd} 50$.

Extent of reduction in total metal in soil.

\begin{tabular}{|c|c|c|c|}
\hline \multirow{2}{*}{ Metals } & \multirow{2}{*}{$\begin{array}{c}\text { Concentration } \\
\left(\mathbf{m g ~ k g}^{-1}\right)\end{array}$} & \multicolumn{2}{|c|}{ Soil metal content $\left(\mathbf{m g ~ k g}^{-\mathbf{1}}\right)$} \\
\cline { 3 - 4 } & 50 & Initial & Final \\
\hline $\mathbf{C u}$ & 100 & 49.9 & 48.5 \\
\hline $\mathbf{C u}$ & 25 & 98.9 & 95.2 \\
\hline $\mathbf{C d}$ & 50 & 23.2 & 22.6 \\
\hline $\mathbf{C d}$ & & 48.3 & 47.5 \\
\hline
\end{tabular}

In the same manner several researchers have screened that after the final day of the study the results obtained showed that the metal contents in soil was decreased, 
reduction was found to increase with increasing metal concentrations in soil in $\mathrm{Cd}$, however in the case of $\mathrm{Cu}$ it decreased Mojiri (2011) reported similar high amount of Cd depletion of metal concentration in soil.

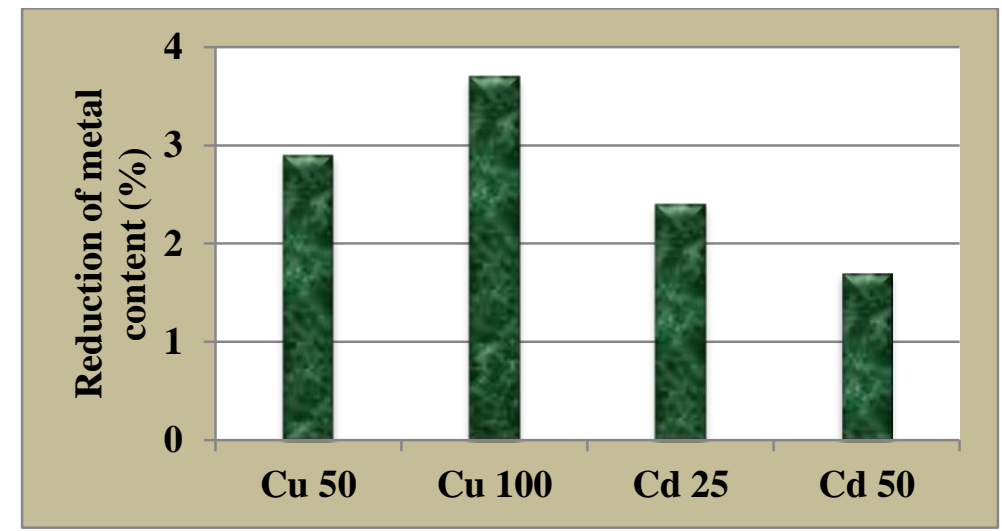

Reduction in total heavy metal content in soil.

Characteristics of metal accumulation:-

The TF, BAC and RCF values evaluate the phytoremedial potential of the plant. Higher TF values indicate more allocation of absorbed metal to above ground biomass. The BAC and RCF values of the plant studied were $<1$ for both increasing concentrations of $\mathrm{Cu}$ and $\mathrm{Cd}$ metals. The ratios were seen to decrease with increasing concentrations of both metals.

Metal accumulation characteristics of $S$. melongena at final day of study.

\begin{tabular}{|c|c|c|c|c|}
\hline \multirow{2}{*}{ Metal } & $\begin{array}{c}\text { Concentration } \\
\left(\mathbf{m g ~ k g}^{-1}\right)\end{array}$ & BAC & RCF & TF \\
\hline \multirow{2}{*}{$\mathbf{C u}$} & 50 & 0.60 & 0.37 & 1.61 \\
\cline { 2 - 5 } & 100 & 0.62 & 0.21 & 2.93 \\
\hline \multirow{2}{*}{$\mathbf{C d}$} & 25 & 0.47 & 0.49 & 0.85 \\
\cline { 2 - 5 } & 50 & 0.17 & 0.39 & 0.43 \\
\hline
\end{tabular}

The $\mathrm{TF}$ values for $\mathrm{Cu}$ concentrations were $>1$ whereas for $\mathrm{Cd}$ concentrations were $<1$. Translocation trend was observed in the order $\mathrm{Cu} 100>\mathrm{Cu} 50>\mathrm{Cd} 25>\mathrm{Cd} 50$. Fitz and Wenzel, 2002 reported that plants with BAC and $\mathrm{TF}>1$ are for efficient phytoextraction, plant must be able to sequester the greater amount of bio-available metal from the soil in its roots and also translocate the major portion of this accumulated metal to above ground biomass (Blaylock and Huang, 2000). Yoon et al. (2006) reported Phyla nodiflora having TF value of 12 and 6.3 for $\mathrm{Cu}$ and $\mathrm{Zn}$. 
Similarly Varun et al. (2015) demonstrated BAC and TF $>1$ in Datura stramonium for $\mathrm{Cu}, \mathrm{Cr}$ and As; Chenopodium murale for $\mathrm{Zn}, \mathrm{Cd}$ ad $\mathrm{Cu}$; Lycopersicon esculentum for $\mathrm{Cd}, \mathrm{Cu}$ and As; Poa annua for $\mathrm{Pb}$ and $\mathrm{Cu}$; Cannabis sativa for $\mathrm{Cr}$. On the bases of biomass potential the test plant species holds promise.

A significant fraction of metals can be stored at root level, especially in polyannual species contributing to long term stabilization of pollutants. Many metal tolerant plants species, particularly grasses, escape toxicity through a metal exclusion mechanism and are therefore better suited for phytostabilization than phytoextarction (Baker, 1981; Mac Farlane et al., 2007). This mechanism may be responsible for low $\mathrm{TF}$ of Cd in S. melongena. In light of the low RCF seen in the test plant it cannot be clearly labelled as a phytostabilizer. But due to higher biomass accumulation in $S$. melongena, it cannot be discounted straightaway.

\section{Chlorophyll contents in S. melongena. in samples:-}

Photosynthesis basically is necessary biological mechanism which is extremely important for photosynthetic organisms and governs their metabolism related to growth and survival in harsh conditions. Metallic pressure ( $\mathrm{Pb}, \mathrm{Cd}, \mathrm{As}, \mathrm{Cr}$ and $\mathrm{Zn}$ etc.) at higher concentrations in soil causes ill effects on an overall growth and metabolism of plants. Chlorophyll, the green pigment is most abundant and mandatory pigment required for this process and is directly affected by environmental factors. In S. melongena. chlorophyll 'a' and 'b' decreased in all plants treated with both the metals $\mathrm{Cu}$ and $\mathrm{Cd}$ compared to control. $\mathrm{Cd}$ was more phytotoxic than $\mathrm{Cu}$ at both concentrations between the successive days of the study (15, 30 and 60). Chl. ' $a$ ' content was > than Chl. ' $b$ ' in the test plant and higher dose of $\mathrm{Cd}\left(50 \mathrm{mg} \mathrm{kg}^{-1}\right)$ was also seen to reduce the Chl. content both ' $a$ ' and ' $b$ ' respectively.Total Chl. content in the test plant was inhabited by $\mathrm{Cu}$ and $\mathrm{Cd}$ at both concentrations and total $\mathrm{Chl}$. declined in all plants amended with $\mathrm{Cu}$ and $\mathrm{Cd}$.. Similar findings have been revealed by Dey et al. (2014) in Camellia sinensis L. that at higher $\mathrm{Cu}$ concentrations the level of Chl. content progressively decreased. Heavy metals are known to interfere with Chl. synthesis either through direct inhibition of an enzymatic step or by inducing deficiency of an essential nutrient. The amount of Chl. was reduced in Triticum aestivum on $\mathrm{Cu}$ enriched soil ( Lanaras et al., 1993) and in Brassica oleracea var. exposed to $\mathrm{Cu}$, Co and $\mathrm{Cr}$ (Chatterjee and chatterjee, 2000). Qian et al. (2009) summarized his study revealing the deleterious effects of $\mathrm{Cd}$ and $\mathrm{Cu}$ on $\mathrm{Chl}$. ' $\mathrm{a}$ ', 'b' and total $\mathrm{Chl}$ in Chlorella vulgaris and showed that $\mathrm{Cu}$ significantly inhibited all these parameters. 
Effect of Cu on chlorophyll content of S. melongena at successive days of study.

\begin{tabular}{|c|c|c|c|c|}
\hline & \multirow{2}{*}{ Conc. (mg kg-1) } & \multicolumn{3}{|c|}{ Chlorophyll 'a' [ $\mathrm{mg} \mathrm{g}^{-1}$ fw] } \\
\hline & & 15 DAT & 30 DAT & 60 DAT \\
\hline Control & 0 & $1.99 \pm 1.2$ & $2.05 \pm 1.2$ & $2.11 \pm 0.6$ \\
\hline \multirow{2}{*}{$\mathbf{C u}$} & 50 & $1.77 \pm 0.9$ & $1.92 \pm 1.4$ & $2.07 \pm 0.5$ \\
\hline & 100 & $1.61 \pm 0.5$ & $1.84 \pm 0.9$ & $1.92 \pm 1.4$ \\
\hline & & \multicolumn{3}{|c|}{ Chlorophyll 'b' [ $\left.\mathrm{mg} \mathrm{g}^{-1} \mathbf{f w}\right]$} \\
\hline Control & 0 & $1.85 \pm 0.9$ & $1.90 \pm 0.9$ & $2.04 \pm 0.4$ \\
\hline \multirow{2}{*}{$\mathbf{C u}$} & 50 & $1.73 \pm 0.9$ & $1.80 \pm 0.95$ & $1.96 \pm 1.0$ \\
\hline & 100 & $1.61 \pm 0.9$ & $1.74 \pm 0.22$ & $1.90 \pm 1.3$ \\
\hline & & \multicolumn{3}{|c|}{ Total chlorophyll [ $\left.\mathrm{mg} \mathrm{g}^{-1} \mathrm{fw}\right]$} \\
\hline Control & 0 & $3.84 \pm 2.49$ & $3.95 \pm 3.19$ & $4.15 \pm 1.62$ \\
\hline \multirow{2}{*}{$\mathbf{C u}$} & 50 & $3.50 \pm 2.29$ & $3.72 \pm 2.85$ & $4.03 \pm 2.29$ \\
\hline & 100 & $3.22 \pm 1.86$ & $3.58 \pm 2.63$ & $3.82 \pm 1.94$ \\
\hline
\end{tabular}

Effect of Cd on chlorophyll content of $S$. melongena at successive days of study.

\begin{tabular}{|c|c|c|c|c|}
\hline \multirow{2}{*}{} & \multirow{2}{*}{ Conc. $\left(\mathbf{m g ~ k g}^{-1}\right)$} & \multicolumn{3}{|c|}{ Chlorophyll 'a' $\left[\mathbf{~ m g ~ g}^{-\mathbf{1}} \mathbf{~ f w}\right]$} \\
\cline { 3 - 5 } & & 15 DAT & 30 DAT & 60 DAT \\
\hline \multirow{2}{*}{ Control } & 0 & $1.99 \pm 0.3$ & $2.05 \pm 2.6$ & $2.11 \pm 2.6$ \\
\hline \multirow{2}{*}{ Cd } & 25 & $1.74 \pm 0.2$ & $1.88 \pm 0.1$ & $2.05 \pm 2.6$ \\
\cline { 2 - 5 } & 50 & $1.54 \pm 1.7$ & $1.76 \pm 0.2$ & $1.91 \pm 0.3$ \\
\hline \multirow{2}{*}{ Control } & 0 & $1.85 \pm 1.0$ & $1.9 \pm 1.0$ & $2.04 \pm 1.0$ \\
\hline \multirow{2}{*}{ Cd } & 25 & $1.63 \pm 0.7$ & $1.78 \pm 0.1$ & $1.92 \pm 0.9$ \\
\cline { 2 - 5 } & 50 & $1.45 \pm 0.4$ & $1.68 \pm 0.9$ & $1.84 \pm 0.9$ \\
\hline
\end{tabular}




\begin{tabular}{|c|c|c|c|c|}
\hline \multicolumn{2}{|c|}{} & \multicolumn{3}{c|}{ Total chlorophyll [ mg g $\mathbf{~}^{-1} \mathbf{f w}$ ] } \\
\hline \multirow{2}{*}{ Control } & 0 & $3.84 \pm 2.4$ & $3.95 \pm 3.1$ & $4.15 \pm 1.6$ \\
\hline \multirow{3}{*}{ Cd } & 25 & $3.37 \pm 1.9$ & $3.66 \pm 2.9$ & $3.97 \pm 3.3$ \\
\cline { 2 - 5 } & 50 & $2.99 \pm 2.0$ & $3.44 \pm 2.0$ & $3.75 \pm 2.7$ \\
\hline
\end{tabular}

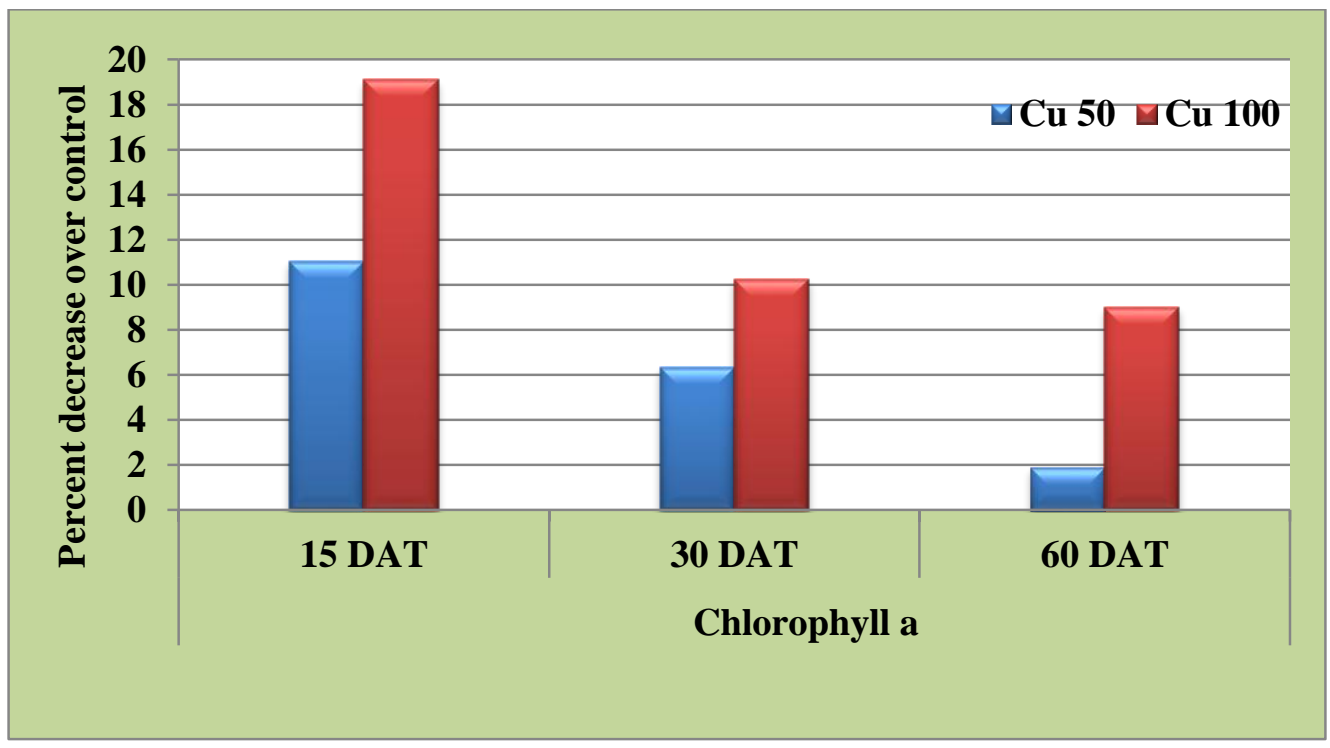

[a]

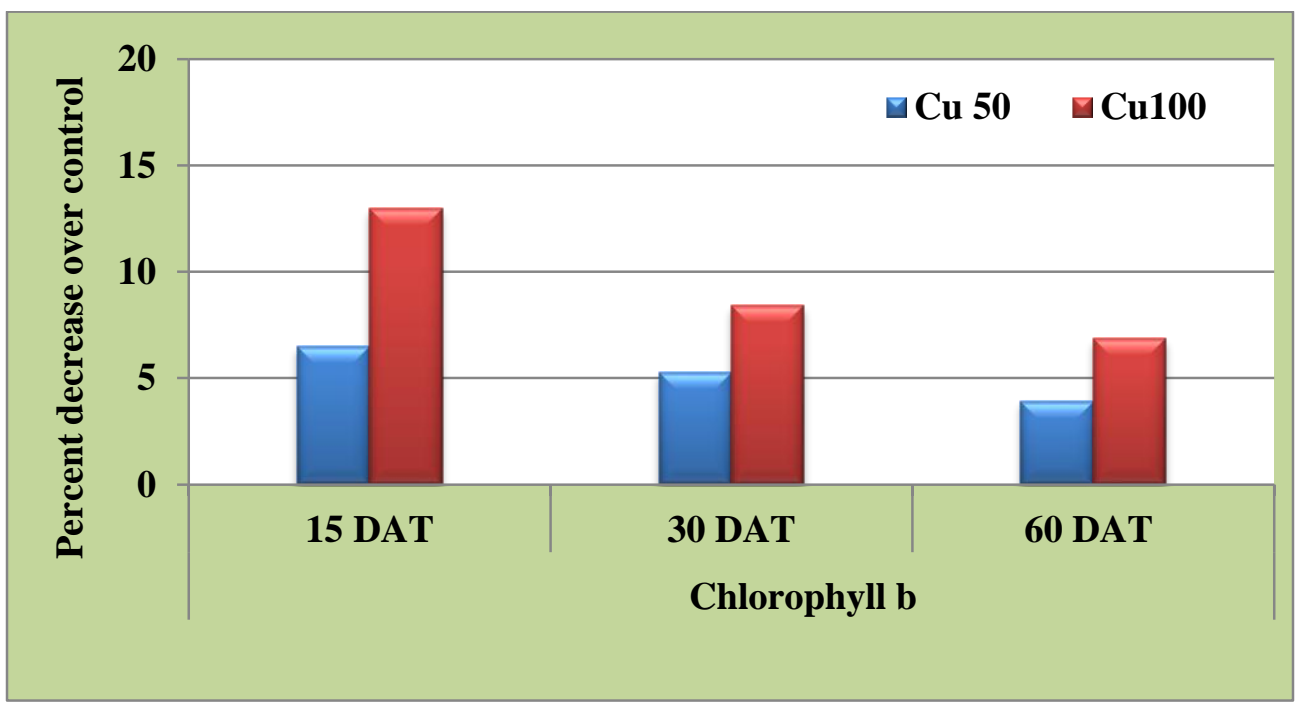

[b] 


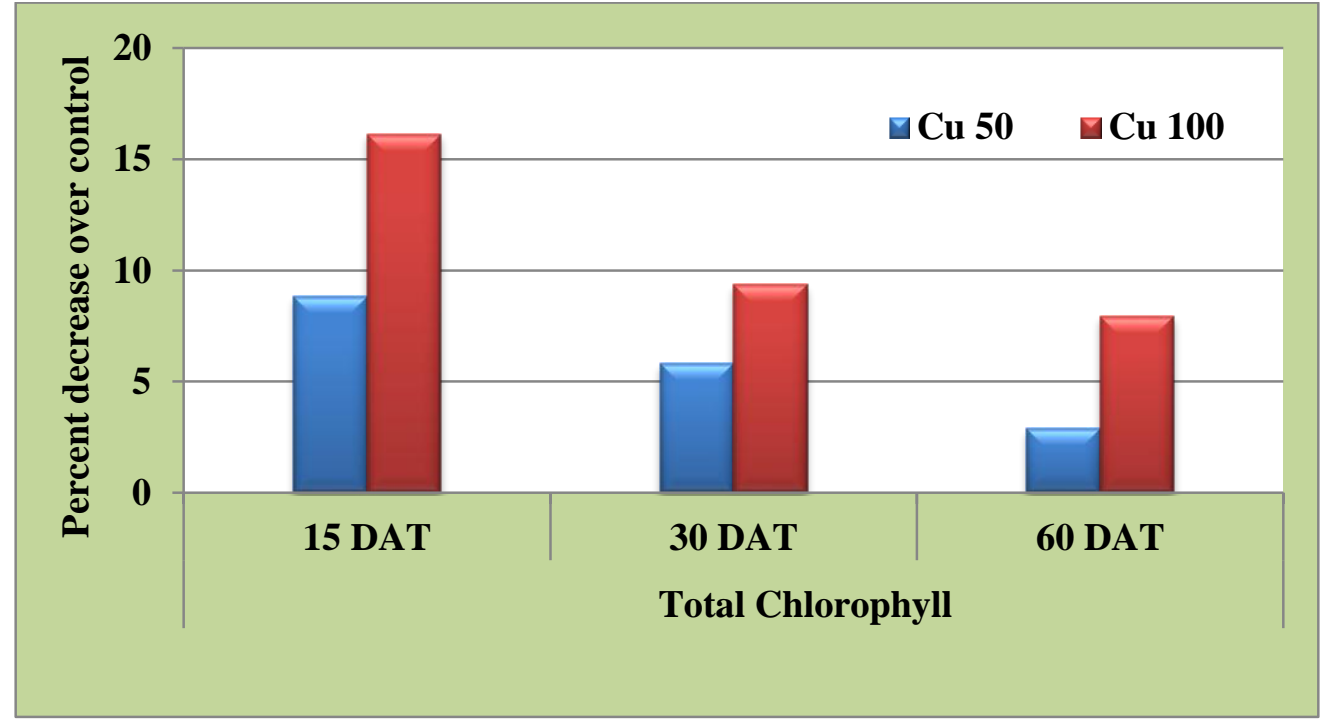

[c]

Figs. 1(a-c): Effect of $\mathrm{Cu}$ on chlorophyll content of $S$. melongena at successive days of study.

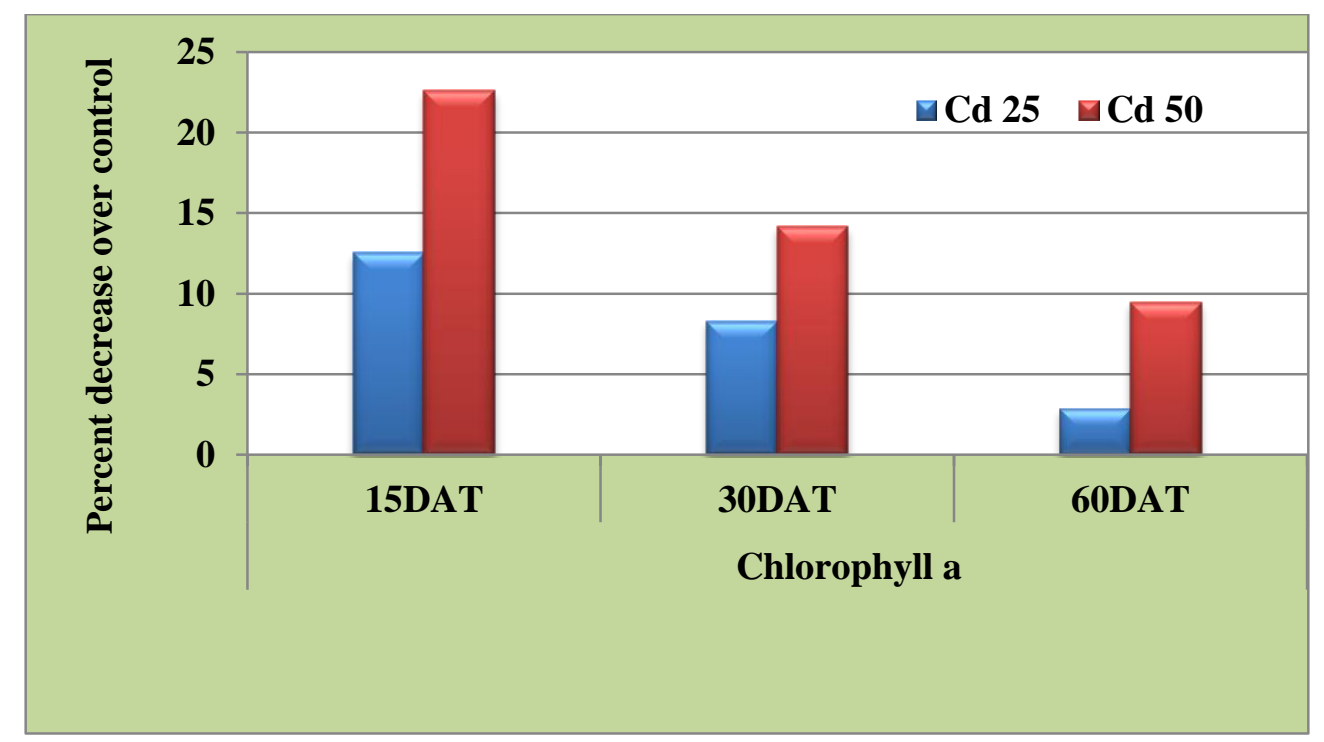

[a] 


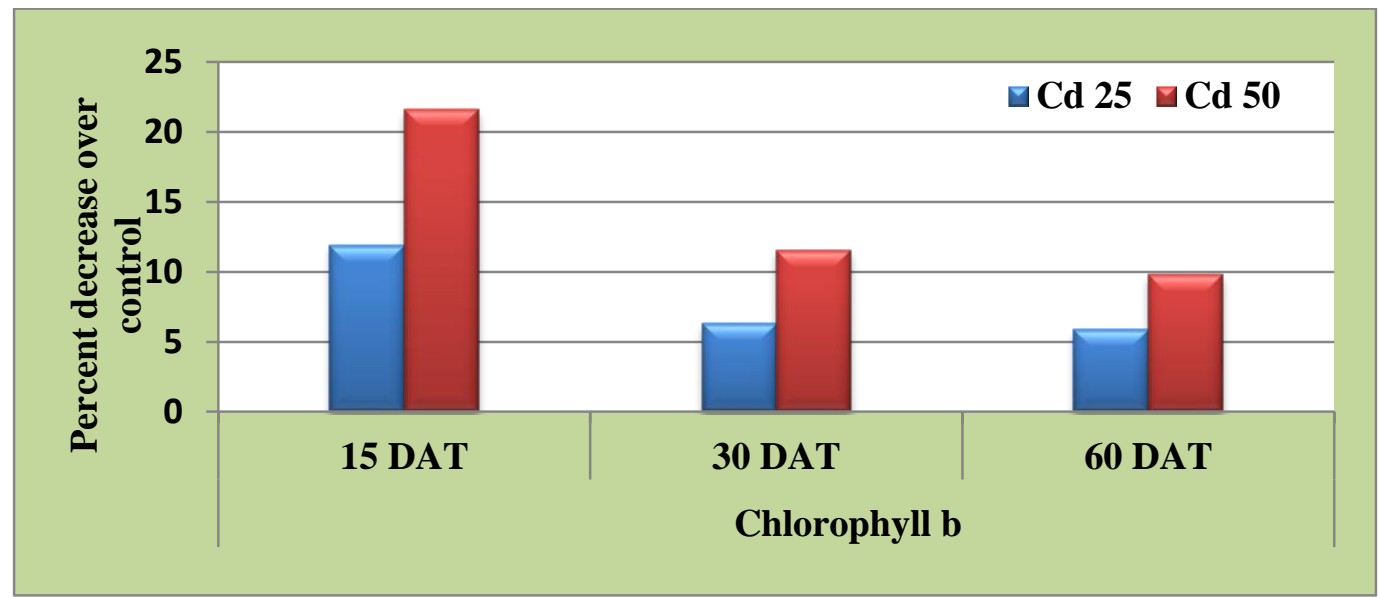

[b]

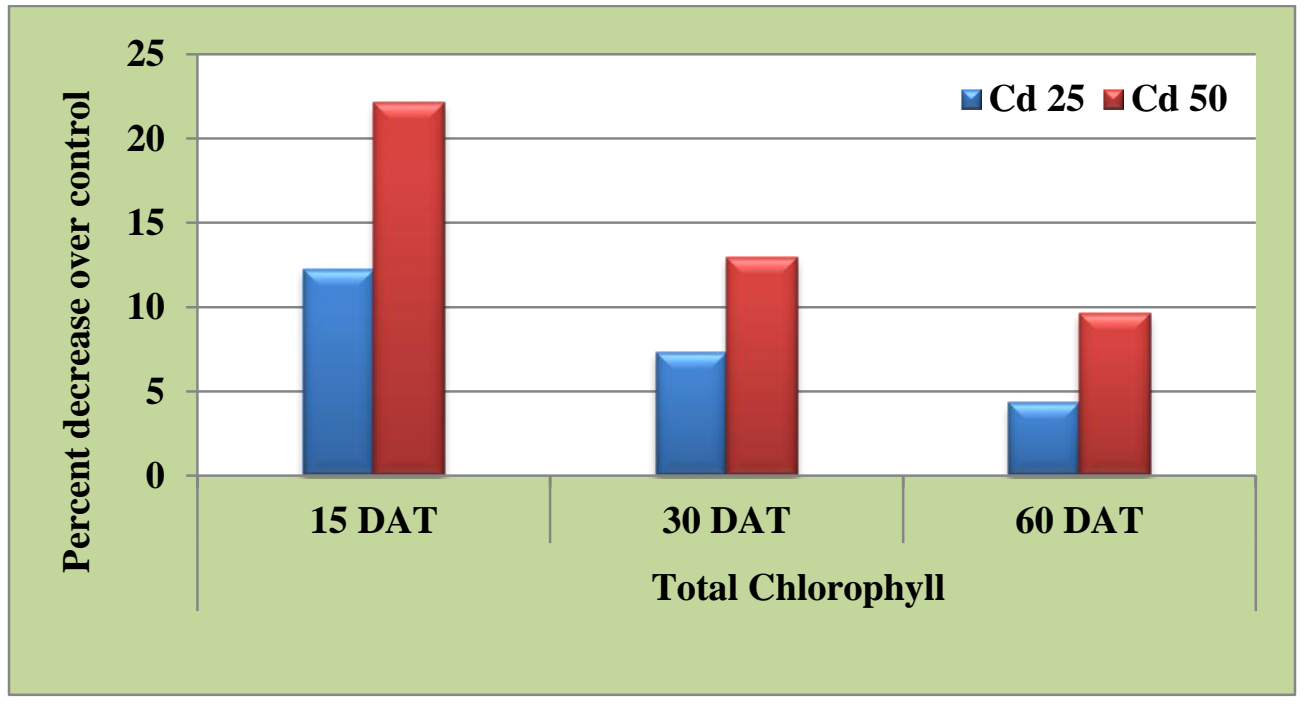

[c]

Figs. 2(a-c): Effect of $\mathrm{Cd}$ on chlorophyll content of $S$. melongena at successive days of study.

Proline content in S. melongena leaf samples:-

Proline, an osmoregulant or protectant, accumulates under heavy metal stress and give rise to a series of reaction which generates numerous free radical by altered levels of major anions and accumulations (Alia and Saradhi, 1991). It increases the stress tolerance of plants and is also an important part of structural protein and enzyme helps in repair process (Chris et al., 2006). Proline content in S. melongena in leaf samples gradually increased with increasing concentrations of both metals $\mathrm{Cu}$ and $\mathrm{Cd}$ in comparison to control at successive days of the study (15,30 and 60). Cd was seen to 
be more phytotoxic in comparison to $\mathrm{Cu}$.

Effect of copper and cadmium on Proline content of $S$. melongena at successive days of study.

\begin{tabular}{|c|c|c|c|c|}
\hline \multirow{2}{*}{ Metals } & $\begin{array}{c}\text { Concentration } \\
\left(\mathbf{m g ~ k g}^{-1}\right)\end{array}$ & \multicolumn{3}{|c|}{ Proline $\left(\boldsymbol{\mu g} \mathbf{g}^{-1} \mathbf{f w}\right)$} \\
\cline { 2 - 5 } & 0 & $0.34 \pm 0.1$ & $0.36 \pm 0.16$ & $0.36 \pm 0.15$ \\
\hline \multirow{2}{*}{ Control } & 50 & $0.5 \pm 0.3$ & $0.42 \pm 0.09$ & $0.38 \pm 0.17$ \\
\hline \multirow{2}{*}{$\mathrm{Cu}$} & 100 & $0.58 \pm 0.06$ & $0.52 \pm 0.04$ & $0.44 \pm 0.09$ \\
\cline { 2 - 5 } & 25 & $0.52 \pm 0.04$ & $0.43 \pm 0.09$ & $0.39 \pm 0.16$ \\
\hline \multirow{2}{*}{ Cd } & 50 & $0.63 \pm 0.15$ & $0.55 \pm 0.05$ & $0.47 \pm 0.08$ \\
\cline { 2 - 5 } & & & DAT & 60 DAT \\
\hline
\end{tabular}

Proline accumulation in plants can serve as biomarker of heavy metal stress and it has been suggested that proline might protect plants from heavy metal toxicity (Farago and Mullen,1979; Smimoff and Cumbs, 1989). According to Handique and Handique (2009), toxic heavy metals like $\mathrm{Pb}, \mathrm{Hg}$ and $\mathrm{Cd}$ induced higher proline accumulation in lemongrass following short term exposure than long term exposure.

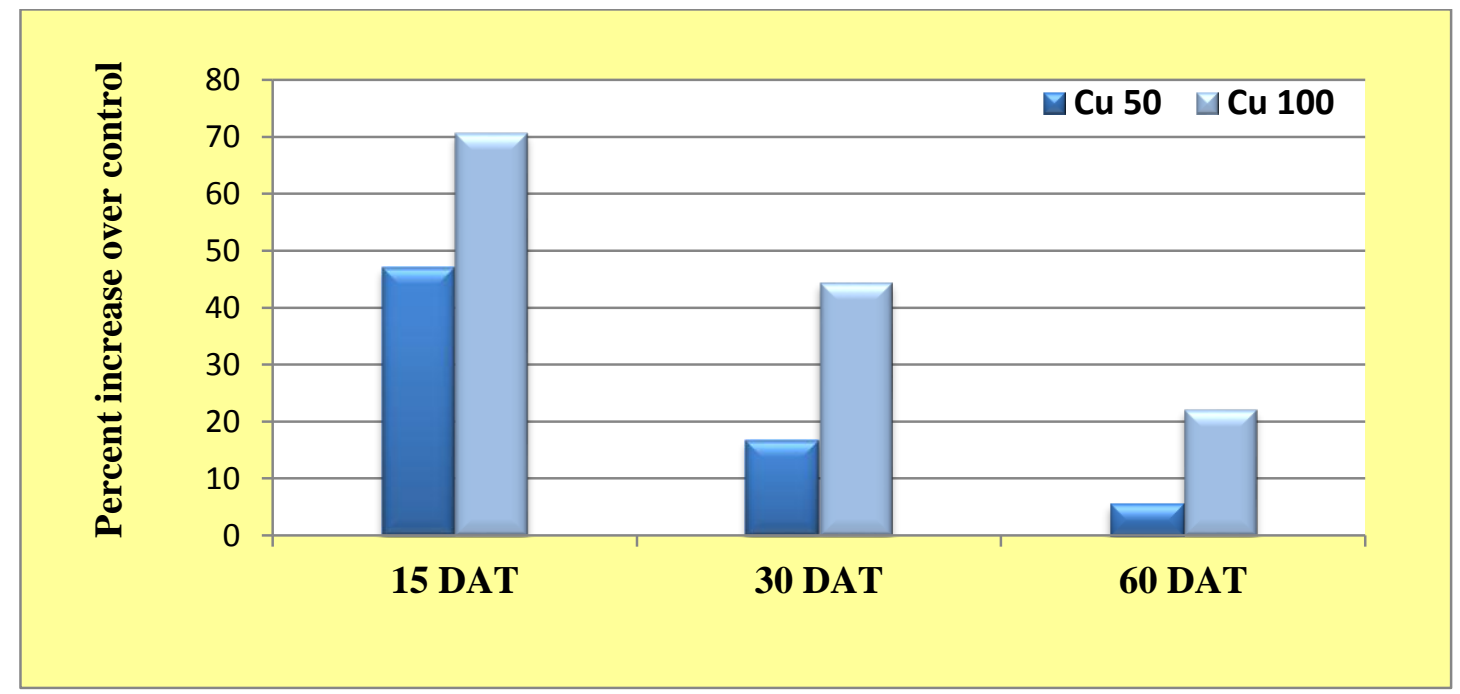

Effect of $\mathrm{Cu}$ on proline content of $S$. melongena at successive days of study. 


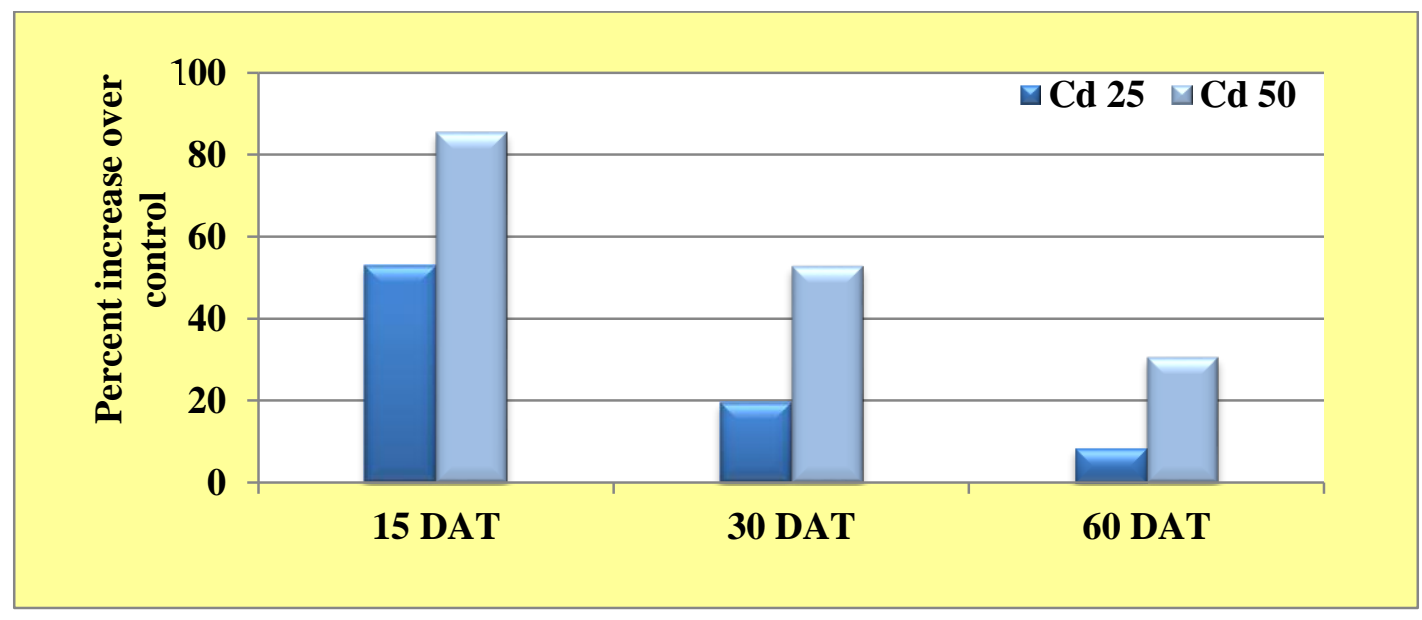

Effect of Cd on proline content of S. melongena at successive days of study.

\section{Metallic effect on root and shoot length of S. melongena:-}

Addition of $\mathrm{Cu}$ and $\mathrm{Cd}$ at both concentrations to the growth matrix was seen to inhabit growth in terms of root and shoot length in all treated plants as compared to control in successive days of study (30 and 60). Roots were affected more than shoots in test plant and the inhibition proportionally increased with the concentration of both metals. However, the inhibition seemed to decreased as the study progressed. Between the two metals tested, Cd was more inhibited of growth.

Effect of $\mathrm{Cu}$ and $\mathrm{Cd}$ on root and shoot length of $\mathrm{S}$. melongena at successive days of study.

\begin{tabular}{|c|c|c|c|c|c|}
\hline \multirow{2}{*}{ Metal } & Concentration & \multicolumn{2}{|c|}{ Root length $(\mathbf{c m})$} & \multicolumn{2}{c|}{ Shoot length $(\mathbf{c m})$} \\
\cline { 3 - 6 } & $\left(\mathbf{m g ~ k g}^{-1}\right)$ & 30 DAT & 60 DAT & 30 DAT & 60 DAT \\
\hline \multirow{2}{*}{ Control } & 0 & $7.3 \pm 2.2$ & $9.2 \pm 3.0$ & $17.4 \pm 4.7$ & $19.9 \pm 1.6$ \\
\hline \multirow{2}{*}{ Cu } & 50 & $6.8 \pm 2.3$ & $9.0 \pm 1.0$ & $16.8 \pm 4.9$ & $19.6 \pm 5.9$ \\
\cline { 2 - 6 } & 100 & $6.2 \pm 2.8$ & $8.6 \pm 1.5$ & $16.2 \pm 3.0$ & $19.2 \pm 5.4$ \\
\hline \multirow{2}{*}{ Cd } & 25 & $6.6 \pm 2.3$ & $8.8 \pm 2.2$ & $16.4 \pm 4.5$ & $19.3 \pm 6.7$ \\
\cline { 2 - 6 } & 50 & $5.9 \pm 2.4$ & $8.2 \pm 1.7$ & $15.8 \pm 5.4$ & $19.0 \pm 7.0$ \\
\hline
\end{tabular}




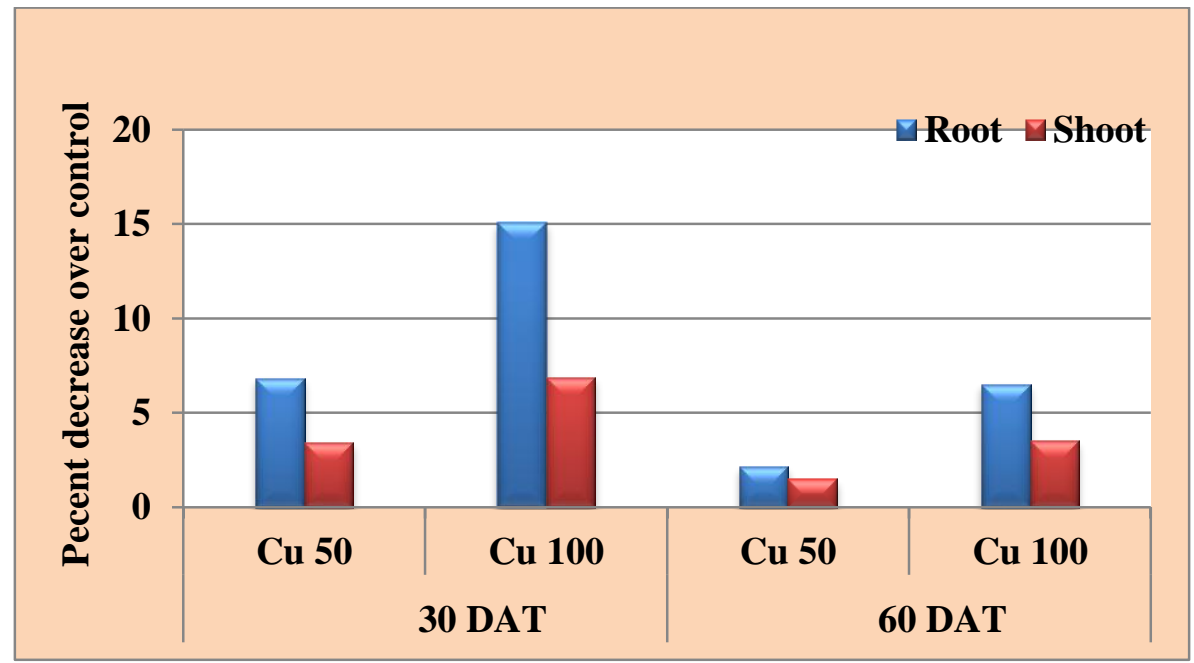

Effect of Cu on root and shoot length of $S$. melongena at successive days of study.

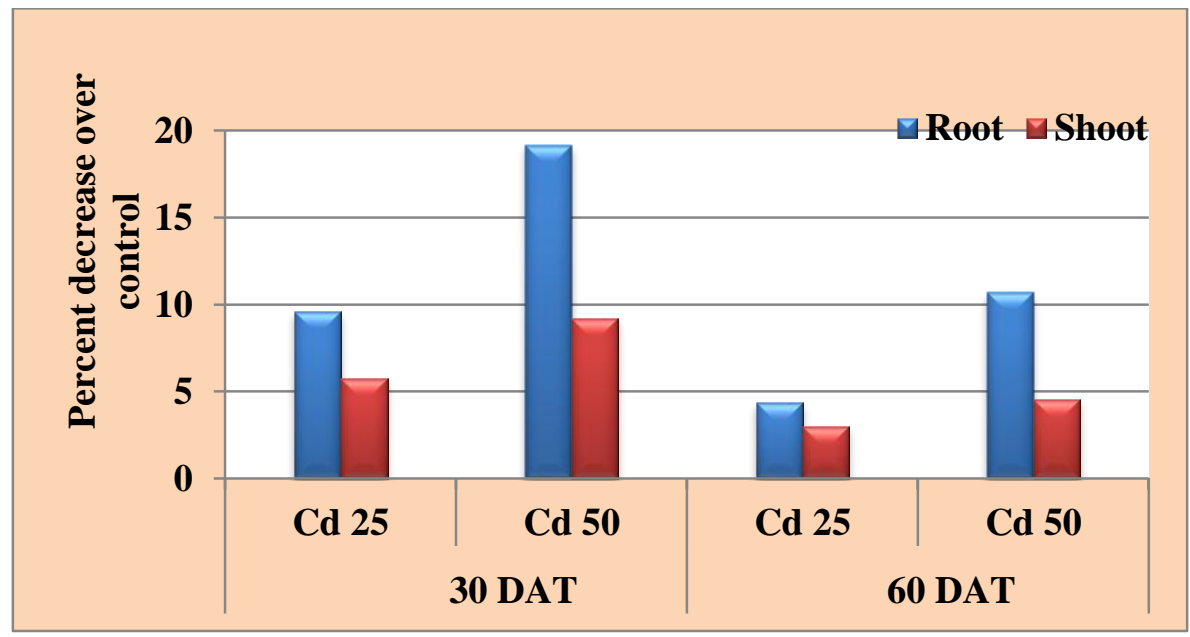

Effect of Cd on root and shoot length of S. melongena at successive days of study.

Several researchers have screened similar results and revealed the influence of various metals on growth. Manivasageperumal et al. (2011) elucidated that lower dose of $\mathrm{Cu}$ in Vigna radiate significantly increased the growth nut at higher doses reverse was seen. According to Hirve and Bafna (2013) Cd adversely and significantly influenced the growth paramerters of seedlings on increasing the concentration of $\mathrm{Cd}$.

\section{Metallic Effect on root and shoot biomass of $S$. melongena:-}

Biomass is a biological material derived from living organisms. Root and shoot weight collectively refers to biomass production and biomass ultimately refers to the 
plant productivity. Heavy metals are known to reduce the biomass production. Roots of the test plant were affected more than the shoots but a gradual increase was noticed as the study progressed. The readings were comparable to control at final day (60). The effect was more pronounced due to $\mathrm{Cd}$ at its both concentrations 25 and $50 \mathrm{mg}$ $\mathrm{kg}^{-1}$ respectively.

Effect of copper and cadmium on dry biomass of root and shoot of S. melongena at the final day of the study.

\begin{tabular}{|c|c|c|c|c|c|}
\hline \multirow{2}{*}{ Metal } & \multirow{2}{*}{$\begin{array}{c}\text { Concentration } \\
\left(\mathbf{m g ~ k g}^{-1}\right)\end{array}$} & \multicolumn{2}{|c|}{ Root biomass (g) } & \multicolumn{2}{c|}{ Shoot biomass (g) } \\
\cline { 3 - 6 } & 0 & $0.11 \pm 0.06$ & $0.13 \pm 0.10$ & $0.54 \pm 0.43$ & $0.58 \pm 0.53$ \\
\hline \multirow{2}{*}{ Control } & 50 & $0.09 \pm 0.07$ & $0.12 \pm 0.09$ & $0.48 \pm 0.44$ & $0.54 \pm 0.51$ \\
\hline \multirow{2}{*}{ Cu } & 100 & $0.06 \pm 0.04$ & $0.10 \pm 0.08$ & $0.44 \pm 0.23$ & $0.51 \pm 0.42$ \\
\cline { 2 - 6 } & 25 & $0.07 \pm 0.04$ & $0.11 \pm 0.06$ & $0.45 \pm 0.25$ & $0.52 \pm 0.38$ \\
\hline \multirow{2}{*}{ Cd } & 50 & $0.05 \pm 0.01$ & $0.09 \pm 0.07$ & $0.41 \pm 0.24$ & $0.49 \pm 0.34$ \\
\cline { 2 - 6 } & & &
\end{tabular}

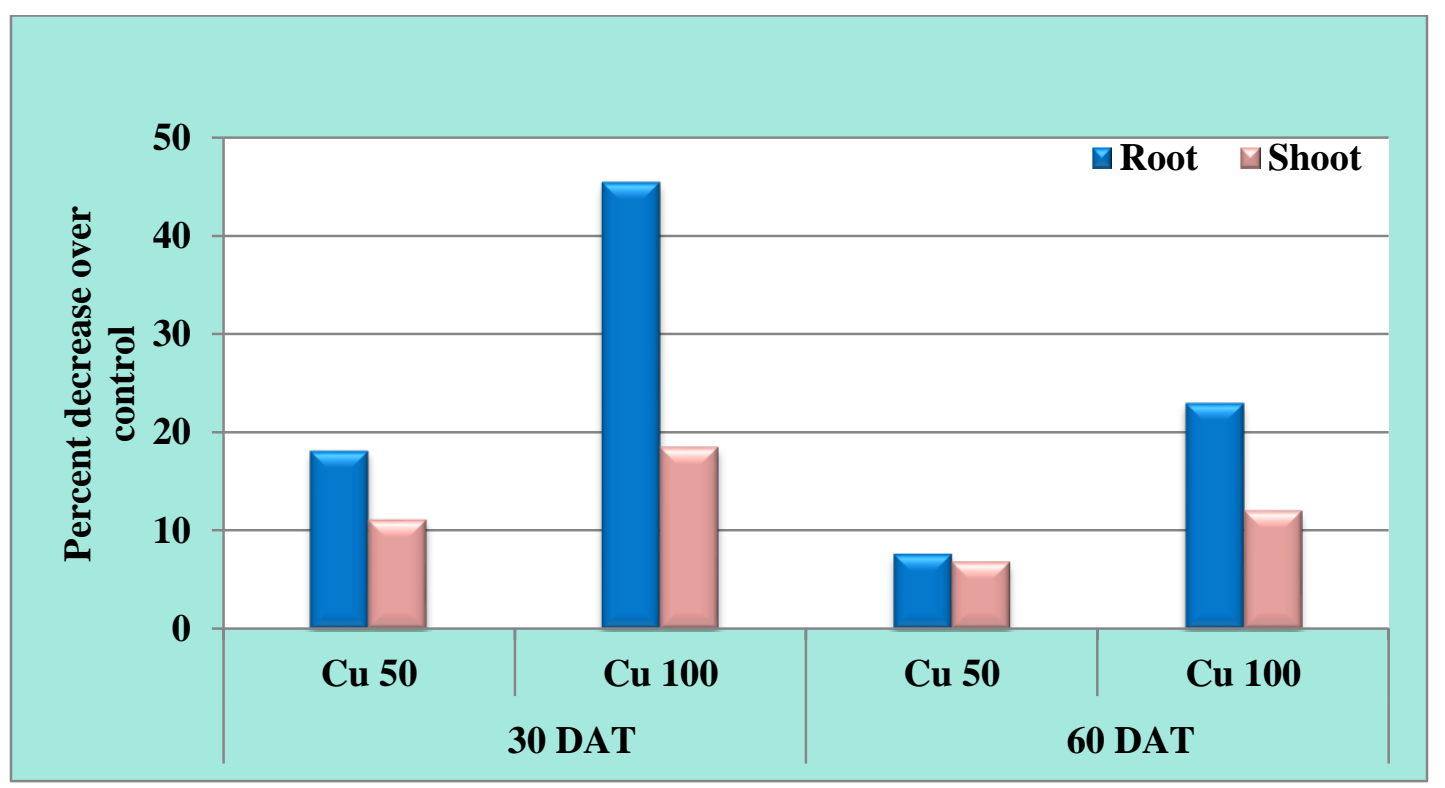

Effect of copper on dry biomass of $S$. melongena at the final day of the study 


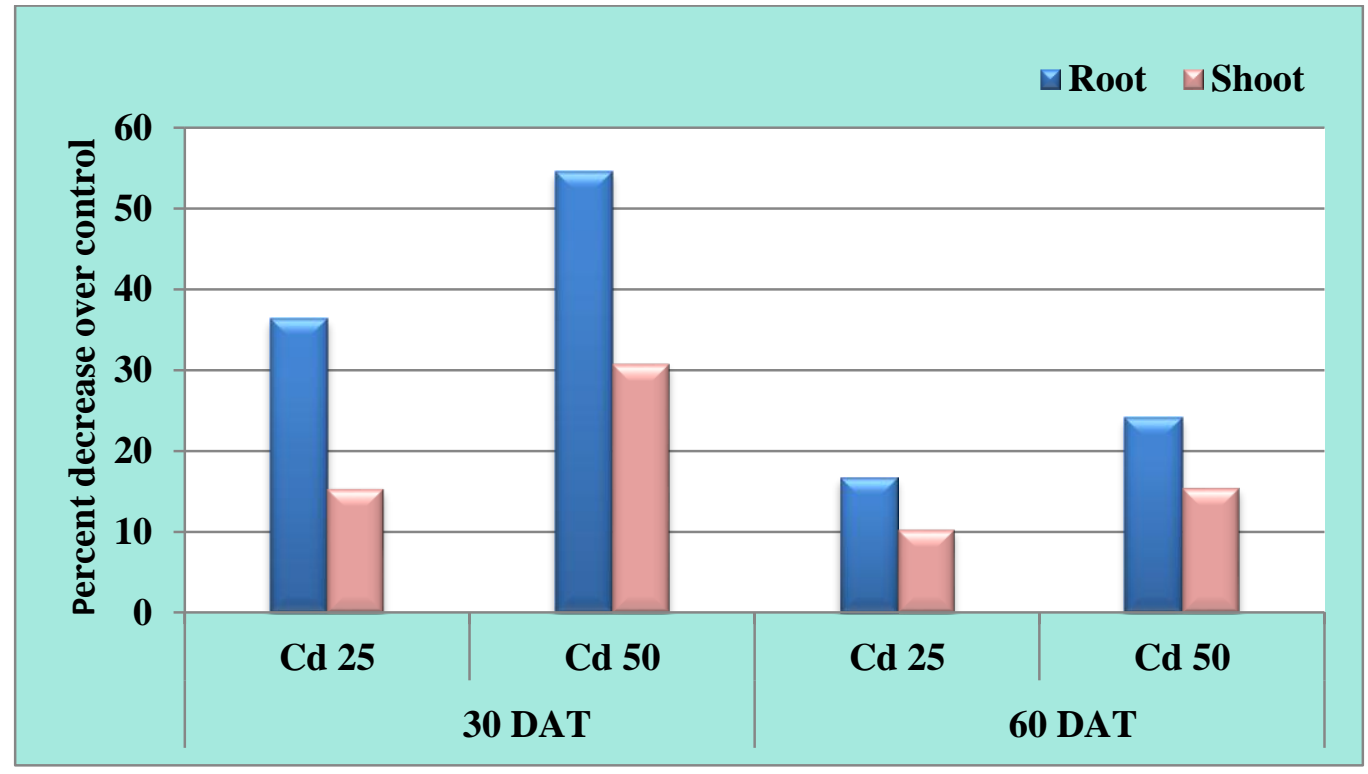

Effect of copper on dry biomass of $S$. melongena at the final day of the study.

Similar work conducted by many researchers showed similar results Chen (2000) on vetiver growth for $\mathrm{Cu}, \mathrm{Pb}, \mathrm{Zn}, \mathrm{Cd}$ and $\mathrm{As}$ and revealed that high contents of metals limited the growth. According to Manivasageperumal et al., (2011) reported the influence of $\mathrm{Cu}$ on Vigna radiate and observed that dry biomass increased compared to control.

\section{CONCLUSION}

Soil is one of the natural resources being over exploited globally due to increased industrial, agricultural and human activities. Urban soils are increasingly acting as a sink for a wide range of contaminants including heavy metals due to rapid pace of development. The most dangerous heavy metals are $\mathrm{Pb}, \mathrm{Hg}, \mathrm{Cd}, \mathrm{Sn}, \mathrm{Cr}, \mathrm{Zn}$ and $\mathrm{Cu}$. Phytoremediation may be a feasible and practical 'natural' remediation technique for soils. At present it is an effective and affordable technological solution use to extract or remove inactive metals and metal pollutants from contaminated soil.

The test plant could not be categorized exclusively as a phytoextractor/phytostabilizer for either $\mathrm{Cu}$ or $\mathrm{Cd}$. However, it was seen to translocate $\mathrm{Cu}$ to shoots quite efficiently. Although an ideal plant species for phytoremediation should have a high biomass with a high metal accumulation capacity, in nature both are seldom found together. Even then, metal accumulation and tolerance are known to be species specific. Hence, a low biomass plant with a very high metal accumulation capacity or a high biomass plant with enhanced metal uptake potential can both give comparable results. In addition to these characteristics, versatility of the candidate plant to tolerate metal contaminants 
is also an asset. Thus based on the accumulation potential, $\mathrm{Cu}$ and $\mathrm{Cd}$ tolerance, and good biomass produced by $S$. melongena, it still holds promise for phytoremedial purposes and future studieas.

\section{REFERENCES}

[1] Ali, M. B. (1999). Physico-chemical characteristics and pollution level of Lake Nainintal (U.P., India): Role of macrophyte and phytoplankton in biomonitoring and phytoremediation of toxic metal ions. Chemosphere. 39(12): 2171-2182.

[2] Alia, P. and Saradhi, P.P. (1991). Proline accumulation under heavy metal stress. J. Plant Physiol. 138: 534-538.

[3] Baker, A. J. M. (1981). Accumulators and excluders - strategies in the response of plants to heavy metals. J. Plant Nutr. 3: 643-654.

[4] Blaylock, M. J. and Huang, J. W. (2000). Phytoextraction of metals. In: Raskin, I. and Ensley, B.D. (eds.) Phytoremediation of toxic metals: using plants to clean-up the environment. New York, John Wiley \& Sons, Inc., pp. $53-70$.

[5] Chantachon, S., Kruatrachue, M., Pokethitiyook, A., Upatham, S., Tantanasarit, S. and Soonthornsarathool, C. (2004). Phytoextraction and accumulation of lead from contaminated soil by vetiver grass: laboratory and simulated field study. Water Air Soil Pollut. 154(1-4): 37-55.

[6] Chatterjee, J. and Chatterjee, C. (2000). Phototoxicity of cobalt,chromium and copper in cauliflower. Environ. Pollut. 109: 69-74.

[7] Chen, H. M., Zeng, C. R., Tu, C. and Shen, Z. G. (2000). Chemical Methods and Phytoremediation of Soil Contaminated with Heavy Metals. Chemosphere. 41(1-2): 229-234.

[8] Chris, A., Zeeshan, M., Abraham, G. and Prasad, S. M. (2006). Proline accumulation in Clindrospermum sp. Environ. Exp. Bot. 57: 145-159.

[9] Dey, S., Mazumder, P. B. and Paul, S. B. (2014). Effect of copper on growth and chlorophyll content in tea plants (Camellia sinensis (L.) O. Kuntze). Int. J. Res. Appl. Nat. Soc. Sci. 2:223-230.

[10] Fageria, N. K., Baligar, V. C. and Clark, R. B. (2002). Micronutrients in crop production. Adv. Agron. 77: 189-272.

[11] Farago, M. E. and Mullen, W. A. (1979). Plants which accumulate metals. A possible copper-proline complex from the roots of Ameria maritime. Inorg. Chim. Acta. 32:L93-L 94. 
[12] Fitz, W. J. and Wenzel, W. W. (2002). Arsenic transformation in the soilrhizosphere-plant system, fundamentals and potential application of phytoremediation. J. Biotechnol. 99: 259-278.

[13] Handique, G. K. and Handique, A. K. (2009). Proline accumulation in lemongrass (Cymbopogon flexuosus Stapf.) due to heavy metal stress. J. Environ. Biol. 30: 299-302.

[14] Herrero, E. M., Lopez-Gonzalvez, A., Ruiz, M. A., Lucas-Garcia, J. A. and Barbas, C. (2003). Uptake and distribution of Zinc, Cadmium, Lead and Copper in Brassica napus var. oleifera and Helianthus annus grown in contaminated soils. Int. J. Phytoremediation. 5(2): 153-167.

[15] Hirve, M. and Bafna, A. (2013). Effect of Cadmium exposures on growth and biochemical parameters of Vigna radiata seedlings. Int. J. Environ. Sci. 4: 315-322.

[16] Intawongse, M. and Dean, J. R. (2006). Uptake of heavy metals by vegetable plants grown on contaminated soil and their bioavailability in the human gastro intestinal tract. Food Addit. Contam. 23(1): 36-48.

[17] Kupper, H., Lombi, E., Zhao, F. J. and McGrath, S. P. (2000). Cellular compartmentation of cadmium and zinc in relation to other elements in the hyperaccumulatorArabidopsis halleri. Planta. 212: 75-84.

[18] Lanaras, T., Moustakas, M., Symeoni, D. S. L., Diomantoglou, S. and Karatagli, S. (1993). Plant metal content, growth responses and some photosynthetic measurements of field-cultivated wheat growing on ore bodies enriched in $\mathrm{Cu}$. Physiol. Plant. 88: 307-314.

[19] Liang, C. C., Li, T., Xiao, Y. P., Liu, M. J., Zhang, H. B. and Zhao, W. Z. (2009). Effects of inoculation with arbuscular mycorrhizal fungi on maize grown in multi-metal contaminated soils. Int. J. Phytoremediation. 11: 692703.

[20] MacFarlane, G. R., Koller, C. E. and Blomberg, S. P. (2007). Accumulation and partitioning of heavy metals in mangroves: A synthesis of field-based studies. Chemosphere. 69(9): 1454-1464.

[21] Manivasageperumal, R., Vijayarengan, P., Balamurugan, S. and Thiyagarajan, G. (2011). Effect of copper on growth, dry matter yield and nutrient content of Vigna radiata (L.) Wilczek. J. Phytol. 3(3): 53-62.

[22] Marschner, H. (1995). Mineral nutrition of higher plants. 2nd ed. Academic Press, New York.

[23] Mojiri, A. (2011). The Potential of Corn (Zea mays) for phytoremediation of soil contaminated with cadmium and lead. J. Biol. Environ. Sci. 5(13): 17-22. 
[24] Prasad, M. N. V. and Freitas, H. M. O. (2003). Metal hyperaccumulation in plants Biodiversity prospecting for phytoremediation technology. Elect. J. Biotechnol. 6 (3): 285-321.

[25] Qian, H., Li, J., Sun, L., Chen, W., Sheng, G. D., Liu, W. and Fu, Z. (2009). Combined effect of copper and cadmium on Chlorella vulgaris growth and photosynthesis-related gene transcription. Aquat. Toxicol. 94: 56-61.

[26] Smimoff, N. and Cumbes, Q. J. (1989). Hydroxyl radical scavenging activity of compatible solute. Phytochem. 28: 1057-1060.

[27] Toppi, S. D. L. and Gabbrielli, R. (1999). Response to cadmium in higher plants. Environ. Exp. Bot. 41: 105-130.

[28] USEPA (United States Environmental Protection Agency) (2005). Use of Field-Scale Phytotechnology for Chlorinated Solvents, Metals, Explosives and Propellants, and Pesticides: Status Report. U.S. Environmental Protection Agency, Washington, DC.EPA 542-R-05-002.

[29] Varun, M. D'Souza, R., Favas, P., Pratas, J. and Paul, M. S. (2015). Utilization and Supplementation of Phytoextraction Potential of Some Terrestrial Plants in Metal- Contaminated Soils. In: Ansari, A. A., Gill, S. S., Gill, R., Lanza, G. R. and Newman, L. (Eds.). Phytoremediation-Management of Environmental Contaminants, Volume 1. Springer, Switzerland. pp. 177200.

[30] Varun, M., D'souza, R., Pratas, J. and Paul, M. S. (2011a). Phytoextraction potential of Prosopis juliflora (Sw.) DC. with specific reference to lead and cadmium. Bull. Environ. Contam. Toxicol. 87: 45-49.

[31] Yoon, J., Caox., Zhou, Q. and Ma, L. Q. (2006). Accumulation of lead, copper and zinc in native plants growing on a contaminated Florida Site. Sci. Total Environ. 368(2-3): 456-464. 
38 Himshweta Singh, Shafeeq Ahmed Malik, Anukrati, Dr. Rohan D' Souza, Dr. Purti Chaturvedi 